\title{
Gender, Space, and Religious Privacy in Amsterdam ${ }^{1}$
}

\author{
Natália da Silva Perez and Peter Thule Kristensen
}

TSEG $18(3): 75^{-106}$

DOI: $10.52024 /$ tseg.1 1043

\begin{abstract}
Silva Perez and Kristensen examine the intersection of gender and religious traditions in the use of space for two distinct religious groups: the Amsterdam beguines, a Catholic community, and the Portuguese Nation, a Jewish community. In the religiously diverse environment of seventeenth-century Amsterdam, only the Dutch Reformed Church was officially authorized to have visible places of worship. Unsanctioned religious groups such as the beguines and the Portuguese Nation had to make arrangements to regulate visibility and access to their spaces of worship. Using privacy as an analytical lens, the authors discuss how strategies employed by the two groups changed over the course of the century.
\end{abstract}

\section{Introduction}

In the seventeenth century, Amsterdam was a religiously diverse city. Though the Dutch Reformed Church enjoyed a privileged position as a religion endorsed by the authorities, other faiths were allowed to be practised in private, and in doing so they sometimes used concealed places of worship. If we understand 'privacy' and 'private' as referring to an ability to regulate access, concealed places of worship enabled un-

1 This research was funded by the Danish National Research Foundation (DNRF 138). We would like to thank our colleagues at the Centre for Privacy Studies, the attendees of the seminar 'Zones of Privacy in the Early Modern Netherlands' (University of Copenhagen - March 2019), and of the seminar 'Perspectives on Privacy in the Seventeenth-Century Netherlands' (Huygens Institute for the History of the Netherlands - January 2020) for their feedback. We are also grateful to the peer-reviewers for their productive comments, which helped improve this article. 
sanctioned religions to be practiced in private inasmuch as these places allowed these communities to regulate exposure and restrain access to their religious practices. In this article, we discuss how gender intersected with religious traditions for the use of space and how it influenced these arrangements to regulate access to spaces of worship used by two unsanctioned religious groups in seventeenth-century Amsterdam. The two groups we study are the Amsterdam beguines, a Catholic community, and the Portuguese Nation, a Jewish community. ${ }^{2}$ Why study these two communities in comparison?

In Amsterdam, regulating the visibility of their spaces of worship was a strategy of privacy for both these two communities. Each arrived at that situation from very different starting points, however. Up until the moment in the seventeenth century when they found themselves practising their religion in private in Amsterdam, Catholics and Sephardic Jews had had opposite paths regarding the visibility and accessibility of their worship spaces. On the one hand, Amsterdam Catholics, in general, had to come to grips with their faith being demoted from its former hegemonic standing in the city. They had gone from having church buildings with high visibility and glamorous prominence to a situation where their places of worship had to be concealed. The beguines of Amsterdam are one case in point. On the other hand, the Jews of the Portuguese Nation were newcomers to Amsterdam. It was there that they had begun again to enjoy religious freedom after a long period of enduring repression and persecution in the Iberian Peninsula. In Spain and Portugal, due to the Inquisition and to widespread prejudice, their religious activities had been driven underground and their synagogues confiscated or destroyed. The Jewish religion had survived among the community members, in great part, thanks to being practised in strict concealment.

While Catholics had gone from high visibility to concealment, the strict need for concealment that had loomed upon Iberian Jews started to subside once they settled in Amsterdam. It was from these utterly different starting points that each religion then engaged in what Benjamin Kaplan termed the 'fictions of privacy' that afforded the Reformed Church its privileged status in the city. ${ }^{3}$ Both groups moderated their

\footnotetext{
2 'Nação Portuguesa' or sometimes simply 'Nação' is a common term appearing in historical sources left by the members of the community, which members used to refer to themselves. This community included people from Portugal, Spain, and other locations along the Mediterranean.

3 Benjamin J. Kaplan, 'Fictions of privacy. House chapels', in: Idem, Divided by faith. Religious conflict and the practice of toleration in early modern Europe (Cambridge MA 2007).
} 
public visibility in the name of an ostensibly private practice of their religion, all for the sake of preserving the integrity of their religious community in the face of the privileged situation enjoyed by the Reformed Church. We will explore how gender played a role in the organization of space when it came to regulating access to the religious space. Gender contributed to shaping the city-wide compromise on private religious practice.

\section{Socio-political religious context in Amsterdam}

Some background information about the religious diversity of Amsterdam will be useful in this discussion. During the sixteenth century, amidst the spread of the Protestant faith in Holland and in the Habsburg Netherlands more generally, the city of Amsterdam remained a Catholic mainstay. ${ }^{4}$ Even after the Dutch Revolt against the rule of Spain had been going for a while, Amsterdam was the last city to join William the Silent, Prince of Orange, in the fight against Philip II, the Catholic king of Spain, and it only did so after brokering an agreement that protected Catholicism in the city. This agreement, known as Satisfactie, was signed on 8 February 1578 , and guaranteed that the Roman Catholic faith was to remain the only religion officially allowed to be practised in public in Amsterdam. As a result of the Satisfactie, other faiths remained restricted to the private realm. ${ }^{5}$

However, the hegemony of Catholicism in Amsterdam was about to end. In May 1578, three months after the Satisfactie, the city was taken by the Beggars, a group of Calvinist Dutch nobles who also opposed Philip II, though on much stronger terms than those espoused by William the Silent. ${ }^{6}$ This invasion resulted in the Amsterdam city council, which for decades had been in the hands of 'sincere Catholycken', being replaced by a new one consisting of a majority of Calvinists. ${ }^{7}$ Because of this change, which came to be known as Alteratie, church buildings in the city were repurposed for the use of the Reformed Church, ${ }^{8}$ monas-

4 Charles Caspers and Peter Jan Margry, 'In the Habsburg's favor (1500-160o)', in: Idem, The miracle of Amsterdam. Biography of a contested devotion (Notre Dame 2019).

5 S.A.C. Dudok van Heel, 'Waar waren de Amsterdamse katholieken in de zomer van ${ }_{15} 85$ ?', Jaarboek Amstelodamum 77:13 (1985).

6 Jonathan Irvine Israel, 'Crisis', in: Idem, The Dutch Republic. Its rise, greatness and fall, 1477-1806 (Oxford 1998) 145 .

7 Idem, 'Society before the Revolt', in: Idem, The Dutch Republic, 127.

8 With the expulsion, a similar repossession of Jewish buildings had happened in Spain. Haim 
teries passed to the control of the city council, and Roman Catholicism lost its place as the only officially allowed religion.

Although the Reformed Church became the only religion endorsed by public authorities, people were not compelled to show allegiance to it, as long as they kept their dissenting confessions private. That is because the Dutch Revolt had been a reaction against, among other grievances, the curtailment of religious freedom: against restrictions on Protestant faiths and against the hegemony of Roman Catholicism in the Netherlands. The proliferation of religious heterodoxy witnessed in early modern Amsterdam and other cities was thus in accordance with values espoused by the revolt. This lenient environment, along with the city's economic prosperity, explains why many immigrants of diverse religious backgrounds found a place to settle in Amsterdam, and why the Roman Catholic faith still enjoyed strong popular support there even after the religious turmoil of the sixteenth century.

At the turn of the seventeenth century, as a way to appease the anxieties of those who favoured a privileged position for the Reformed faith, an unplanned solution to the difficulties of religious diversity quietly arose: as long as the privileged visibility of the Reformed Church was not contested, other faiths were allowed to be practised in private. Soon a number of concealed places of worship belonging to diverse religious groups started to flourish. Known today as schuilkerken - meaning clandestine, concealed, or hidden churches - these spaces were part of the pragmatic, unofficial solution to the problems posed by heterodoxy and existed throughout northern Europe. ${ }^{9}$ In Amsterdam, Roman Catholics had started to use private houses to gather and worship soon after the Alteratie. In these houses, they were able to regulate the access of who could come in or who should stay away from their religious ceremonies. Some examples of these buildings are still extant, such as Ons' Lieve Heer op Solder (Our Lord in the Attic), which now houses a museum. ${ }^{10}$ Other Christian denominations also made use of concealed spaces of worship to avoid scrutiny by the Reformed, and so, too, did the Jewish community upon their arrival in the city.

In this article, we contrast and compare both concealed and visible spaces of worship belonging to the Portuguese Nation and to the be-

Beinart, 'The fate of Jewish communal property', in: Idem, The expulsion of the Jews from Spain, trans. by Jeffrey M. Green (Liverpool 2002), 70, https://doi.org/10.2307/j.ctv4rfr25.11.

9 Kaplan, 'Fictions of privacy', 176.

10 'About the Museum Ons' Lieve Heer Op Solder', Museum Ons' Lieve Heer op Solder, accessed August 2O, 2020, https://opsolder.nl/en/about-the-museum/. 
guines, two different Amsterdam communities compelled to exercise their religion in private in the seventeenth century. Expanding on previous scholarship, we focus specifically on questions of how the gendered norms guided and shaped the spaces of religious privacy for these communities in Amsterdam. Gendered norms had a great influence on the history of each community's religious practices, in private and in public. ${ }^{11}$

\section{From crypto-Judaism to public presence: Amsterdam's Portuguese Nation}

When the first Sephardic merchants started to settle in Amsterdam, they were religiously inconspicuous. They came to Amsterdam ostensibly for business purposes, often as New Christians, and did not seek to emphasize their status as members of a religious minority that had been driven underground. ${ }^{12}$ Miriam Bodian explains that 'the fact that they were to all appearances Christian prevented alarms from sounding among the predikants' of the Dutch Reformed Church. ${ }^{13}$ All in all, they did not show a strong interest in claiming visibility for themselves as being Jewish, a strategy of privacy probably engrained in their behaviour in the Iberian Peninsula.

That is because, in the Iberian Peninsula, Jews had endured sustained persecution since at least the massacres of 1391, when a first wave of forced baptism gave rise to a number of New Christians in Castile and Aragon. ${ }^{14}$ Among those newly converted to Christianity, many maintained strong connections to Jewish practices as well as to oth-

11 Renée Levine Melammed, Heretics or daughters of Israel? The crypto-Jewish women of Castile (New York 1999); Idem, 'Crypto Jewish women and Spanish inquisition', in: Mark D. Meyerson and Edward D. English (eds.) Christians, Muslims, and Jews in medieval and early modern Spain. Interaction and cultural exchange (Notre Dame 200o); Janet Liebman Jacobs, 'Women, ritual, and secrecy. The creation of crypto-Jewish Culture', Journal for the Scientific Study of Religion 35:2 (1996) 97, https://doi. org/10.2307/1387078; Isabella Henriette van Eeghen, Vrouwenkloosters in begijnhof in Amsterdam van de 14 e tot het eind der 16 e eeuw (Amsterdam 1941); Sarah Joan Moran, Unconventual women. Religion, politics, and image in the court beguinages, 1585-1 713 (Unpublished PhD dissertation Brown University 2010), http://search.proquest.com/docview/763156185/abstract/525072BC134546C6PQ/1.

12 Miriam Bodian, Hebrews of the Portuguese nation. Conversos and community in early modern Amsterdam (Bloomington 1999) 28-29.

13 Ibid., 58.

14 François Soyer, 'Castillian conversos and Jews in Portugal c. 1480 - c 1495', in: Idem, The persecution of the Jews and Muslims of Portugal. King Manuel I and the end of religious tolerance (1496-7) (Boston and Leiden 2007) 84, http://ebookcentral.proquest.com/lib/kbdk/detail.action?docID=468421. 
er Jews who did not convert to Catholicism. Some of those forcibly converted sought refuge in Portugal in order to go back to the Jewish faith, something that we can attest from an undated piece of legislation passed by King João I of Portugal sometime after 1391, which protected these refugees. ${ }^{15}$ Most New Christians, however, remained in Castile and Aragon. Some of the converted embraced their new religion, but others discreetly kept whatever remnants of Judaism they could.

The term 'crypto-Judaism' refers to this practice of Jewish customs in secret, especially with the goal to evade scrutiny by Inquisition authorities; for a long time, crypto-Judaism was the only way in which many of those forcibly converted could exercise their faith. In other words, secrecy was the only safe strategy to regulate access to themselves, since even the slightest suspicion of links with Judaism could land someone in trouble with the authorities, putting their life at risk. In 1492, when Queen Isabel and King Ferdinand expelled from their kingdom Jews who refused to embrace Catholicism, another wave of forced conversions increased the numbers of New Christians practising crypto-Judaism. Renée Levine Melammed notes that the Catholic Monarchs blamed Jews for corrupting New Christians into being crypto-Jews. The text of their Edict of Expulsion of 1492 even explains that the problem was the visible presence of Jews, especially when there was communication between New Christians and Jews:

We were informed that in these our kingdoms there were some bad Christians who Judaized and apostatized from our holy Christian faith, this being chiefly caused by the communication of the Jews with the Christians is evident and apparent that the great damage to the Christians has resulted from and does result from the participation, conversation, and communication that they have had with the Jews...(italics added $)^{16}$

For those New Christians who practised crypto-Judaism, it was not possible to go to the synagogue in safety, and after 1492, it was not possible at all. The men of the community were deprived of most of their official religious functions, since yeshivas and synagogues - the places

15 “alguũs delles se faziam Christaõs contra suas vontades, e outros se punham nomes de Christaaõs nom seendo bautizabos com padrinhos, e madrinhas, segundo o direito quer; e esto faziam por escapar da morte ataa que se podessem poer em salvo; e que alguũs desses Judeos, e Judias se vierom aos ditos nossos Regnos, e trouverom suas molheres, e filhos, e fazendas..." Ordenações Afonsinas, b. II, title 77, item 1, quoted in Soyer, go.

16 Quoted in Levine Melammed, Heretics or daughters of Israel?, 16. 
where men exercised Jewish learning - were not accessible. Even so, Jewish women's religious obligations were circumscribed to the domestic realm. Levine Melammed explains that 'traditionally the women had kindled lights on Friday evening, prepared Sabbath meals, baked matzah, observed the dietary laws, and the like; now these observances were to become the major symbols of crypto-Judaism. ${ }^{17}$ This spatial division of roles - domestic on the one hand, and in the synagogue and yeshivas on the other - effectively turned women into the main purveyors of religious customs as persecution increased. Within the space of the home, where they could the regulate access of strangers, to a certain extent, women managed to teach members of younger generations that they belonged to a Jewish community. Inquisition records show that women taught others about prayers, fasting, and holidays of the Jewish faith. Inquisition authorities knew of the importance of women in maintaining Jewish customs alive and made efforts to scrutinize their behaviour. Many women were condemned as heretics for judaizing at home. ${ }^{18}$

Demonstrating one's Jewish faith in the Iberian context was dangerous, so strategies of privacy that helped to regulate visibility and access were very important for survival. We have evidence that appropriate religious decoration was one of the tenuous ways in which people could adhere to Judaism, but tending to these visible symbols of faith could attract scrutiny from the Inquisition. We can see this, for example, with the cases of New Christian women like Mencia Rodríguez or Leonor Gutierrez. Mencia Rodríguez was reported in her Inquisition file as having sinned because she 'clean[ed] and adorn[ed] the synagogue's lamps, placing wicks in them and pouring oil inside them. ${ }^{19}$ Leonor Gutierrez was reported as having sinned because of her habit of turning towards the wall the image of the Virgin Mary placed at her bed's headboard every Saturday morning. ${ }^{20}$ With these examples, we can see that religious images and lighting not only affected the appearance of the spaces used by these women and their families, but because of their religious significance for those practising Judaism in secret, they were also evidence of wrongdoing in the eyes of Inquisition authorities.

\footnotetext{
17 Ibid., 32.

18 Renée Levine Melammed, 'Judeo-conversas and Moriscas in sixteenth-century Spain. A study of parallels," Jewish History 24:2 (2010): 16o, https://doi.org/10.1007/s10835-010-9106-y.

19 Renée Levine Melammed, 'Jews and conversas', in: Idem, Heretics or daughters of Israel?, 29.

20 Francisco Cantera Burgos and Carlos Carrete Parrondo, 'La judería de Hita', Sefarad; Madrid 32:2 (1972) 264 .
} 
After the establishment of the Spanish Inquisition in 1480, a number of Castilian New Christians fled in fear of being accused of apostasy. Some of them went to Portugal to try to assimilate back into Jewish life in the Jewish communities native to that country. ${ }^{21}$ With the expulsion of 1492, those Jewish inhabitants of Castile and Aragon who refused to convert to Catholicism also fled in larger numbers, and some of them also went to Portugal. João II, the Portuguese king, had allowed 6oo Jewish families to settle there and had granted a leave of eight months for the rest to move along to other lands. ${ }^{22}$

After King João II's death, and due to pressures from the Spanish monarchs, the Portuguese crown also started taking actions against this mixed group of Jews and New Christians. ${ }^{23}$ In 1497, King Manuel I of Portugal sent back those Castilian New Christians convicted of apostasy by the Spanish Inquisition. In a subsequent edict, he also mandated conversion for all Portuguese Jews and explicitly disallowed them from fleeing Portugal, which created a wave of Portuguese New Christians in addition to those from Castile and Aragon. Finally, in 1536, the Portuguese Inquisition was established to scrutinize the life of Portuguese New Christians suspected of crypto-Judaism. ${ }^{24}$ Despite the prohibition to emigrate from Portugal, many of those forcibly converted managed to flee, and amongst them we find many members of the Amsterdam Portuguese Nation.

Once outside of Iberian territory, the pressure to practice Judaism in secret started to be relaxed. The Sephardic diaspora reached many places, among which were countries along the coast of the Mediterranean, the south of France, and the Low Countries. Dutch cities like Alkmaar and Haarlem, in their attempts to attract the wealthy Portuguese merchants to settle there, had even made appealing offers allowing the practice of Judaism and, under certain conditions, the construction of a synagogue. ${ }^{25} \mathrm{Amsterdam}$ was more attractive for business, so Sephardic

21 François Soyer, 'King Manuel I and the expulsion of the Castilian conversos and Muslims from Portugal in 1497: New Perspectives', Cadernos de Estudos Sefarditas, 8 (2008) 36.

22 Idem, 'Castillian conversos and Jews in Portugal', 102.

23 Idem, 'King Manuel I and the expulsion of the Castilian conversos', 35-49.

24 Still, there was inquisitorial activity in Portugal before that, as Soyer points out: 'Contrary to the general belief that there was no inquisitorial activity in Portugal prior to the establishment of the 'Portuguese' Inquisition in $\mathbf{1 5 3 6}$, there is in fact some evidence that, since the fourteenth century, specially appointed inquisitors had held the power to investigate heretical beliefs and deeds'. Soyer, 'Castillian conversos and Jews in Portugal', 86.

25 David Kromhout and Adri Offenberg, 'Introduction and analysis of the "Remonstrantie" in: Idem, Hugo Grotius's Remonstrantie of 1615. Facsimile, transliteration, modern translations and analysis (Leiden 2019) 17 . 
Jewish immigrants preferred to go there for the time being. In Amsterdam, many who had been forcibly converted to Roman Catholicism had a chance to reconvert to Judaism with the social support of the burgeoning community that called itself the Portuguese Nation, which now started to attract fellow immigrants interested specifically in the religious freedom that was to be found in the city.

In 1618 , the city counted three separate Sephardic Jewish communities, each responsible for its administration and place of worship. ${ }^{26}$ The members of the Portuguese Nation were well aware of the ban on public practices for religions other than the Reformed Church. ${ }^{27}$ In the first years of their settlement, the community ostensibly complied with the Amsterdam ban on public worship. We have evidence of that, for example, regarding Neve Shalom's congregation construction of a synagogue in 1612 . In a notary deed from 31 January 1612 , leaders of the community registered a contract with carpenter 'João' Gerritzen to build a structure to be used as a synagogue. In the document, their use of language is very discreet: they use the word casa (house) and include no explicit indication of the purpose of the construction. The only religiously charged mention is a provision stating that the builder and his contractors should not work from Friday before sunset until Sunday night (covering both Christian and Jewish definitions of the Sabbath), nor during the Holy Week. ${ }^{28}$

Though the language of the document is discreet concerning the purpose of the commission, a closer look at the text reveals a detailed description of the building. Two houses occupied the ground floor, one on each side of the plot. The façade described was quite conventional for houses of that time: Dutch gables with red bricks and joints of white lime, doors and windows facing the front painted green on the outside, a gate with a rounded top separating the front yard from the street. Fol-

26 E.M. Koen, 'Waar en voor wie werd de synanoge van 1612 gebouwd?', Amstelodamum: Maandblad voor de kennis van Amsterdam 57:9 (1970) 209.

27 'Extract uytet register van resolutiën 4 September 1598 van burgemeesteren ende oud burgemeesteren der stadt Amstelredamme dat alhier ter stede geen andere exercitie van religie can noch mach toegelaten worden, als de geene, die in 't openbaer inde Kercken alhier wort geexerceert', in: Jac Zwarts, $D e$ eerste rabbïnen en synagogen van Amsterdam, naar archivalische bronnen (Amsterdam 1929).

28 'Sera obriguado elle Joao Gerritsen nem per sy nem por outrem trabalhar em nehua couza q toque à obra de esta caza desde sesta feria antes do sol posto até domingo a noite nem os dias de toda a somana santa'. 'Notary deed where members of Neve Shalom community hire J. Gerritzsen to build two houses on the Houtburgwal', 31 January 1612, Inventary 5075, 7 (Notary David Mostart), item 62, digitized folios A31408000512 to A31408000515, Gemeente Amsterdam Stadsarchief, https://archief.amsterdam/inventarissen/inventaris/5075.nl.html\#A31408000001. 
lowing a common tendency of other clandestine places of worship, too, the main area of the synagogue would occupy the second floor of the building, on top of the houses, which allowed for greater control of visibility from the street. This main hall on the second floor had the same dimensions as the whole ground floor, approximately 18 by 9 metres. In the front part of this main hall, a camara pendente [hanging room], measuring approximately 2.7 by 4.5 metres and equipped with a separate staircase and entrance, would likely serve as the women's gallery. ${ }^{29}$

The plan for building a women's gallery on the synagogue emerges from a traditional separation between men and women during Jewish prayer, referred to as mehitzah (barrier). The history of this tradition is contested, with different parties claiming that it is 'biblical, late antique, or medieval. ${ }^{30}$ In an overview about the topic, Shira Wolosky explains that 'Rabbinic law established daily communal prayer as an obligation binding only upon men, and the synagogue's central area was institutionalized early on as a male-only space. ${ }^{31}$ Wolosky further clarifies that

The first mention of a mehitzah is in the context of the Second Temple itself, where, however, it is cited as an anomaly. The Temple contained an Inner Court and a Women's Court, but men and women mixed freely in the latter. Separation was instituted specifically with regard to the annual "Water-Drawing Ceremony," simhat beit hashoevah... [as] it was feared... that the free mingling and festive atmosphere of the occasion might lead to kalut rosh, frivolity, and so, according to Mishnah Sukkot 5:2, a tikkun gad$o l$, a "great correction," was instituted; according to Tosefta Sukkkot 4:1, this took the shape of balconies [for women]...

Mehitzah, this traditional barrier or separation, provided an instrument to regulate access between men and women and can thus be understood as a strategy of privacy embedded in the religious tradition. This instrument came to be implemented in a variety of ways according to local customs where the Jewish community was present. Synagogues in the Iberian Peninsula built in Mudéjar style before the expulsion often had a gallery or balcony for women, something we know from ex-

29 'Notary deed where members of Neve Shalom community hire J. Gerritzsen to build two houses on Houtburgwal'.

30 Norma Baumel Joseph, 'Mehitzah. Halakhic decisions and political consequences', in: Susan Grossman and Rivka Haut (eds.) Daughters of the king. Women and the synagogue. A survey of history, halakhah, and contemporary realities (Lincoln 1993) 118.

31 Shira Wolosky, 'Foucault and Jewish feminism. The mehitzah as dividing practice', Nashim. AJournal of Jewish Women's Studies \& Gender Issues; Jerusalem 17 (2009) 11. 


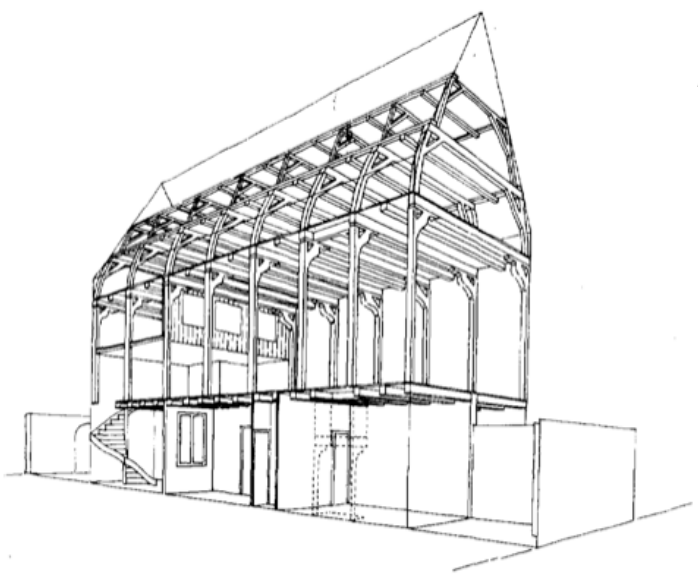

Illustration 1 H.J. Zandkuyl, Reconstruction of an early seventeenth century synagogue (source: see footnote 34 ).

tant buildings and archeological evidence. ${ }^{32}$ The plan to have a hanging room in the Neve Shalom house in Amsterdam suggests a certain continuity with this line of Iberian synagogue architecture. In contrast, other traditions of Judaism implemented separation in other styles, as in the case of weibershule or of ezrot nashim in Polish and German synagogues of the early modern period, which were independent rooms or buildings adjacent to the main synagogue, where women led their own prayers. ${ }^{33}$

In the Neve Shalom building plan sketched above, the women's gallery would have window-like openings to the synagogue's main floor, possibly fitted with latticework. Such screens allowed women to observe from above the rituals conducted by the male leaders but blocked eyesight from the main synagogue floor, preventing the men from looking at the women. Apart from the continuity with Iberian architectural elements, the description of the commissioned building also shows adaptation to what was in vogue in the local Amsterdam architecture, resulting in a house that from outside would not be much different from the neighbouring ones. ${ }^{34}$

The Portuguese Nation sought to comply in all appearances with the ban on public worship for religions other than the Reformed Church,

32 Otto Czekelius, 'Antiguas sinagogas de España', Arquitectura. Revista Oficial De La Sociedad Central de Arquitectos 13:15o (1931) 333, http://www.coam.es/media/Default\%2oFiles/fundacion/biblioteca/ revista-arquitectura-10o/1918-1931/docs/revista-articulos/revista-arquitectura-1931-n15opag326-341.pdf.

33 Wolosky, 'Foucault and Jewish feminism', 11.

34 Based on the description in the notarial record, the architectural historian H. J. Zantkuyl made in 1970 an approximate reconstruction of the design. H.J. Zantkuyl, 'Reconstructie van een vroeg $17 \mathrm{e}$ eeuwse synagoge', Amstelodamum. Maandblad voor de kennis van Amsterdam 57:9 (1970) 199-208. Image used with permission, courtesy of Amstelodamum. 
but their attempts at being discreet received some pushback from authorities. On 8 May 1612, city officials passed a resolution forbidding the congregation members to use this building under construction either as a synagogue or as a home, on penalty of demolition:

...die vande voorseyde natie aen te seggen, dat int voorseyde gebou nyemand vande selve natie sal mogen wonen, noch dat aldaer eenige bijeencompste mach gehouden worden ofte eenige ceremoniën van haerer Religie gepleegt, op pene van demolitie tot de grond vant voorseyde huys ofte gebou....

The way the community's representatives dealt with this resolution speaks to how they sought to remain strategically inconspicuous. According to documents found by E. M. Koen, a member of the Amsterdam city council named Nicolas van Campen was the official owner of the house.$^{36}$ Miriam Bodian and E. M. Koen both postulate that, after the aforementioned resolution forbidding anyone from Neve Shalom to use the house, the community leaders must have sold the building to Van Campen, and then rented it from him to use it as a synagogue, a well-known strategy used for other concealed places of worship. For Bodian, city officials might have been just appeasing the Reformed Church council's complaints against the construction, without any intention to actually punish the members of Neve Shalom. Despite the threat of demolition, the building was allowed to be finished, and it functioned as Neve Shalom's synagogue until the unification of the Sephardic congregations in $1639 .{ }^{37}$ The threatening resolution by the burghomasters and aldermen proved to be toothless.

In 1639, the three independent Sephardic congregations that existed in Amsterdam united as one community called K.K. Talmud Torah. One of their houses of worship was renovated and expanded and became the united community's synagogue. This was an elegant palacelike structure on the Houtgracht, which we can observe in a drawing made in 1695 by Romeyn de Hooghe (when it no longer housed a synagogue), titled De Geweesene Kerk der Joden. ${ }^{38}$

35 'Resolution in which the burghomasters and schepenen prohibit the Portuguese nation to use the house that they are having built as a synagogue', 8 May 1612, Inventary 5075, 10, digitized folio A13259000064, Gemeente Amsterdam Stadsarchief, https://archief.amsterdam/inventarissen/ inventaris/5025.nl.html\#A1325900oo64.

36 E.M. Koen, 'Nicolas van Campen als huiseigenaar van de Portugees-Israelische synagoge', Amstelodamum. Maandblad Voor de Kennis van Amsterdam 58:1 (1971) 117.

37 Bodian, Hebrews of the Portuguese nation, 59.

38 Romeyn de Hooghe, De geweesene kerk der Ioden. Gezicht op de voormalige Portugese synagoge 
Compared to Neve Shalom's concealed synagogue discussed above, the building on the Houtgracht presented striking architectural differences. Barry Stiefel points to the similarities between the Houtgracht building and the Mauritshuis at The Hague, which was designed by Jacob van Campen following the principles of the Dutch baroque. ${ }^{39}$ The architect responsible for the house on the Houtgracht is not known. Like the Mauritshuis, the synagogue façade had typical baroque pilasters extending over two floors and festoons placed under the windows on the prominent first floor. Compared to Mauritshuis, the Houtgracht synagogue façade was even more glamorous, since it made use of the Corinthian order, the most prominent of the classical orders. Having such a fashionable building as their synagogue certainly meant that the Sephardim was visible to the wider Amsterdam community, but since the appearance of the building did not convey its religious purpose, the community still complied with the mandate to practice their religion in private. In other words, having secular decoration on the façade of the building allowed the its religious significance to be modulated, acquiring prominence only inside. We know the interior of the building from a depiction from 1664, attributed to Jan Veenhuysen and titled Der Jooden Tempel of Sinagoge. ${ }^{40}$

In the Houtgracht building, we can also observe the presence of women's galleries. Though we do not have measurements for this building, from the drawing it is possible to conjecture that here the women's galleries took up a larger proportion of the building's space as compared to the Neve Shalom synagogue, for which we do have measurements. We know from the notarial record that the galleries in the Neve Shalom synagogue occupied about one sixth of the structure's space. The exact measures are not available for the house on the Houtgracht, but the sketched interior suggests that this proportion could be approximately one fourth of the interior. Could this apparent increase in space suggest that a larger proportion of the women in the community were attending the synagogue? Absent a detailed description of the building's measurements, it is impossible to answer this question, but other elements also suggest an increased attention to the space dedicated for

aan de Houtgracht te Amsterdam, c 1695, engraving, h 237 mm × w 287 mm, c 1695, RP-P-AO-24-39, Rijksmuseum, http://hdl.handle.net/10934/RMooo1.COLLECT.125117.

39 Barry L. Stiefel, Jews and the renaissance of synagogue architecture, 1450-1 730 (London 2015) 68.

40 Jan Veenhuysen, Der Jooden tempel of sinagoge. Interieur van de Portugese synagoge aan de Houtgracht te Amsterdam, 1664, engraving, h 113 mm × w 140 mm, 1664, RP-P-AO-24-28, Rijksmuseum, http://hdl.handle.net/10934/RMooo1.COLLECT.334067. 


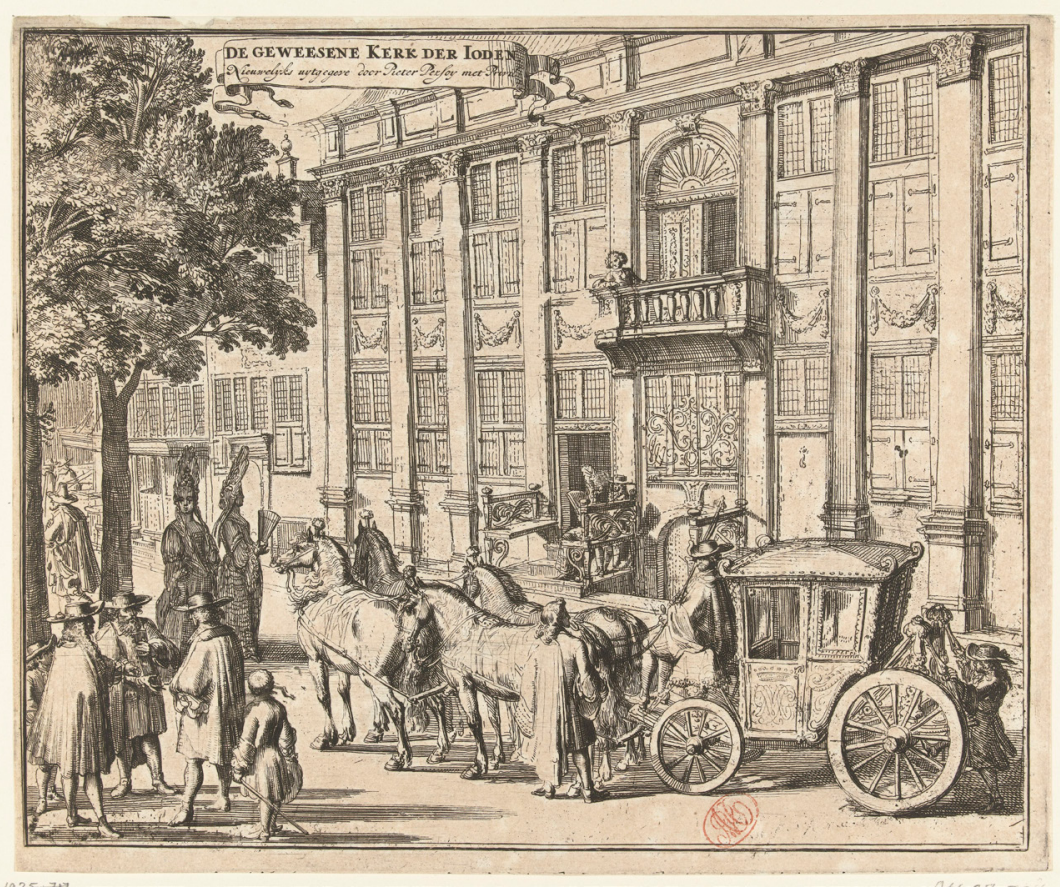

Illustration 2 Romeyn de Hooghe, De geweesene kerk der loden. View of the façade of the former Portuguese synagogue on the Houtgracht in Amsterdam, c 1695 (source: Rijksmuseum RP-PAO-24-39).

women, for example, its decoration in harmony with baroque principles favoured in the Dutch architecture of the time.

The galleries featured latticework that extended from the floor of the balconies to the ceiling, separating that space from the main floor of the synagogue. Blocking sightlines from below, the screen fulfilled the requirement for mehitzah through a rigorous design that nonetheless managed to be in harmony with Dutch baroque symmetry. The attention to aesthetic rules and the proportion of space reserved for the women's section indicate that women could feel that they belonged in the synagogue and could actively participate in Jewish life beyond the home among the Sephardim in Amsterdam. According to Barry Stiefel, the Houtgracht building was the first known example 'where symmetrical lateral balconies specifically for the use of women within the main sanctuary were integrated into a synagogue's design at the time of construction. ${ }^{41}$ The Portuguese Nation was not isolated, however, in giving 


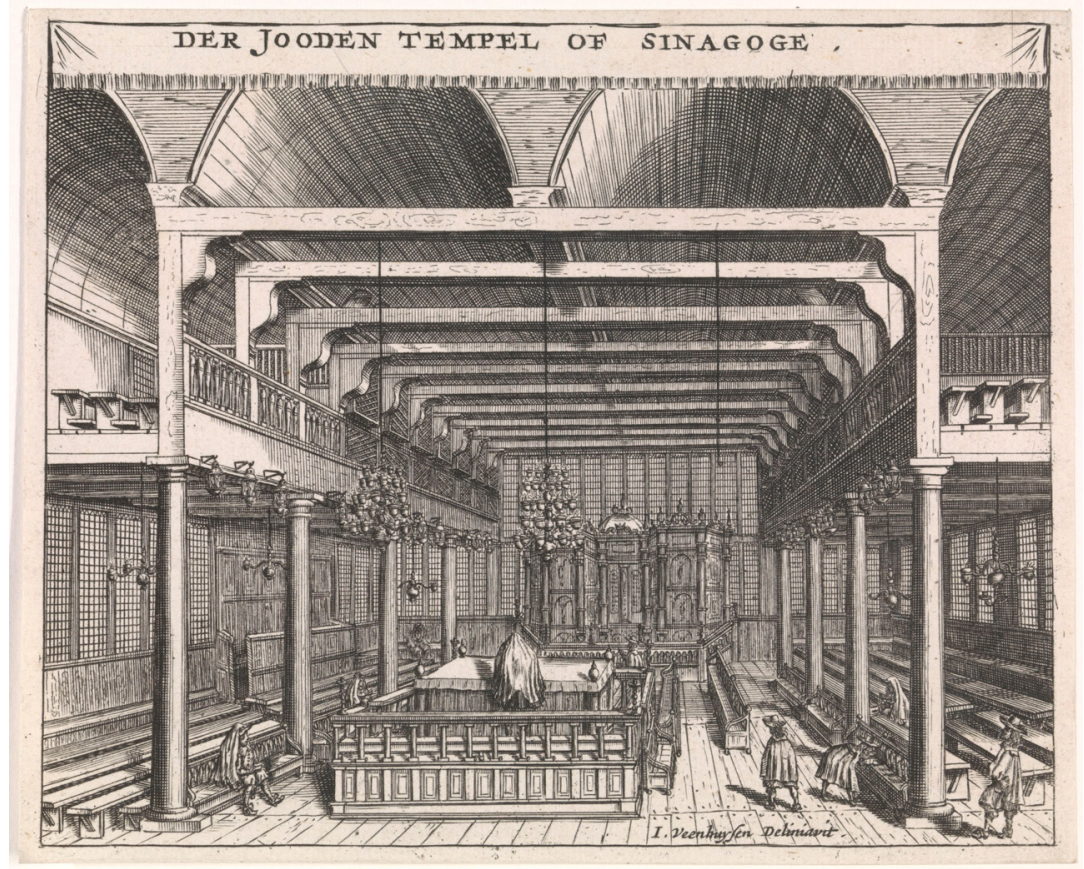

Illustration 3 Jan Veenhuysen, Der Jooden tempel of sinagoge. Interior of the Portuguese synagogue on the Houtgracht in Amsterdam, 1664 (source: Rijksmuseum RP-P-AO-24-28).

more space for women in the synagogue: in early modern Jewish communities all across Europe, as demonstrated by Shira Wolosky's overview, women had more synagogue space for themselves. ${ }^{42}$

When the united community had grown and no longer fit in the Houtgracht synagogue, Rabbi Isaac Aboab petitioned the congregation leaders to expand their place of worship and received enthusiastic support. ${ }^{43}$ Soon they purchased the land where the new place of worship would stand, and hired Elias Bouwman as the architect to guide the project, which also followed principles from the Dutch baroque style. The Sephardic community's public visibility in Amsterdam came to its apogee in 1675 , with the inauguration of the large and elegant synagogue known as Esnoga. This is the only extant building of the three synagogues discussed here. Many contemporary artists documented the building from inside and outside, including Emanuel de Witte in

42 Wolosky, 'Foucault and Jewish feminism', 11-13.

43 'Termo da resolução de 3 Kislev 5431 de se fazer esnoga en novo sitio', 16 November 1670, Inventary 334, 19 Escamoth A, digitized folio Ao1504000356, Gemeente Amsterdam Stadsarchief, https:// archief.amsterdam/inventarissen/inventaris/334.nl.html\#Ao1504000356. 


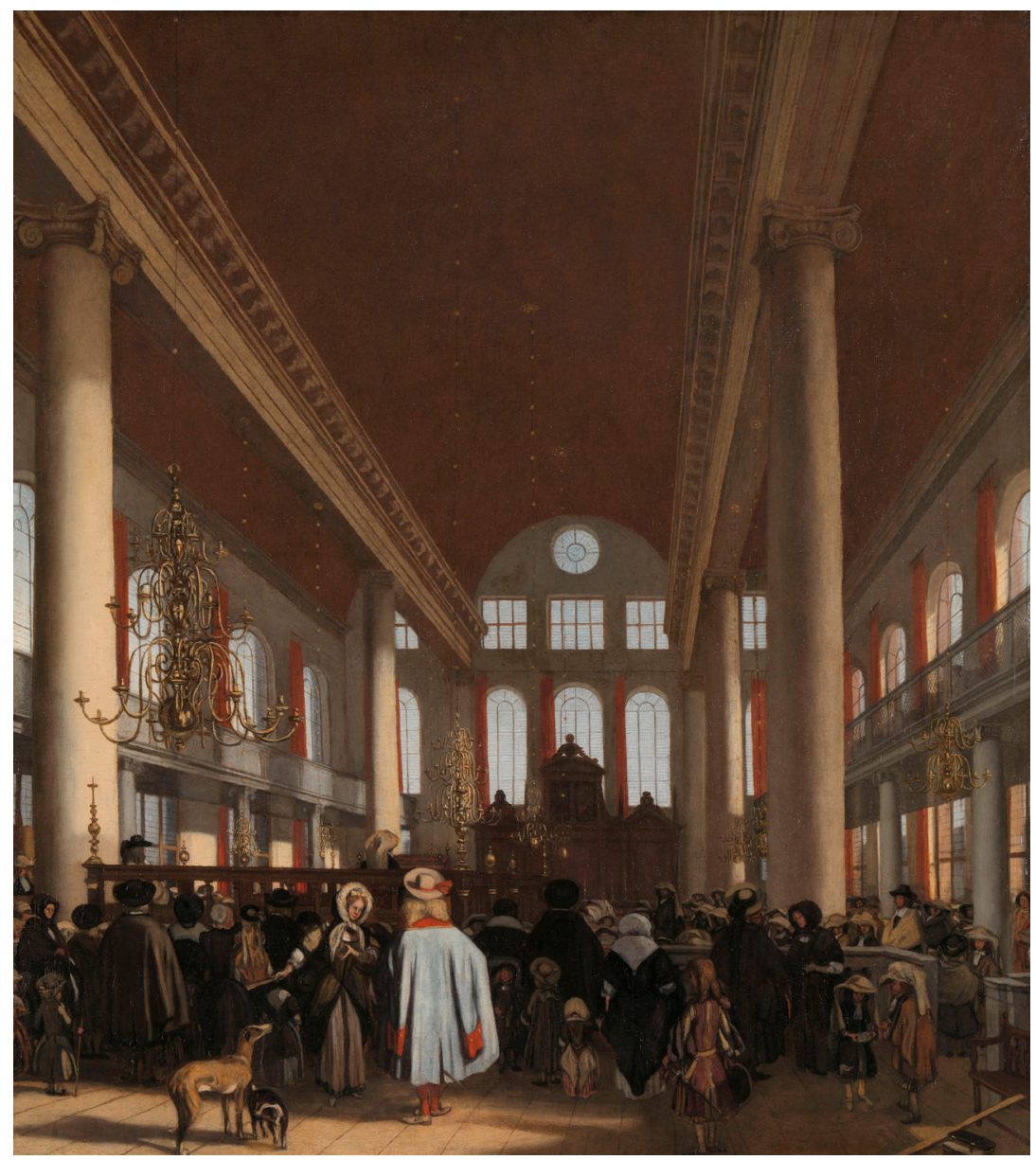

Illustration 4 Emanuel de Witte, Interior of the Portuguese synagogue in Amsterdam, 1680 (source: Rijksmuseum, SK-A-3738).

his painting Interieurvan de Portugese synagoge te Amsterdam ${ }^{44}$ and Romeyn de Hooghe, who produced celebratory engravings for the inauguration ceremony, for example, Interieurvan de Portugese Synagoge te Amsterdam tijdens de inwijding. ${ }^{45}$

The Esnoga is a vast structure of 26 by 38 metres, surrounded by an enclosed courtyard, with a brick façade. This façade was very sim-

44 Emanuel de Witte, Interior of the Portuguese synagogue in Amsterdam, 1680, oil on canvas, $\mathrm{h}$ $110 \mathrm{~cm} \times$ w 99 cm, 168o, Rijksmuseum, http://hdl.handle.net/10934/RMooo1.COLLECT.6584.

45 Romeyn de Hooghe, Interieur van de Portugese synagoge te Amsterdam tijdens de inwijding, 1675, engraving, h $390 \mathrm{~mm} \times \mathrm{w} 498 \mathrm{~mm}, 1675$, Rijksmuseum, http://hdl.handle.net/10934/RMooo1. COLLECT.336465. 


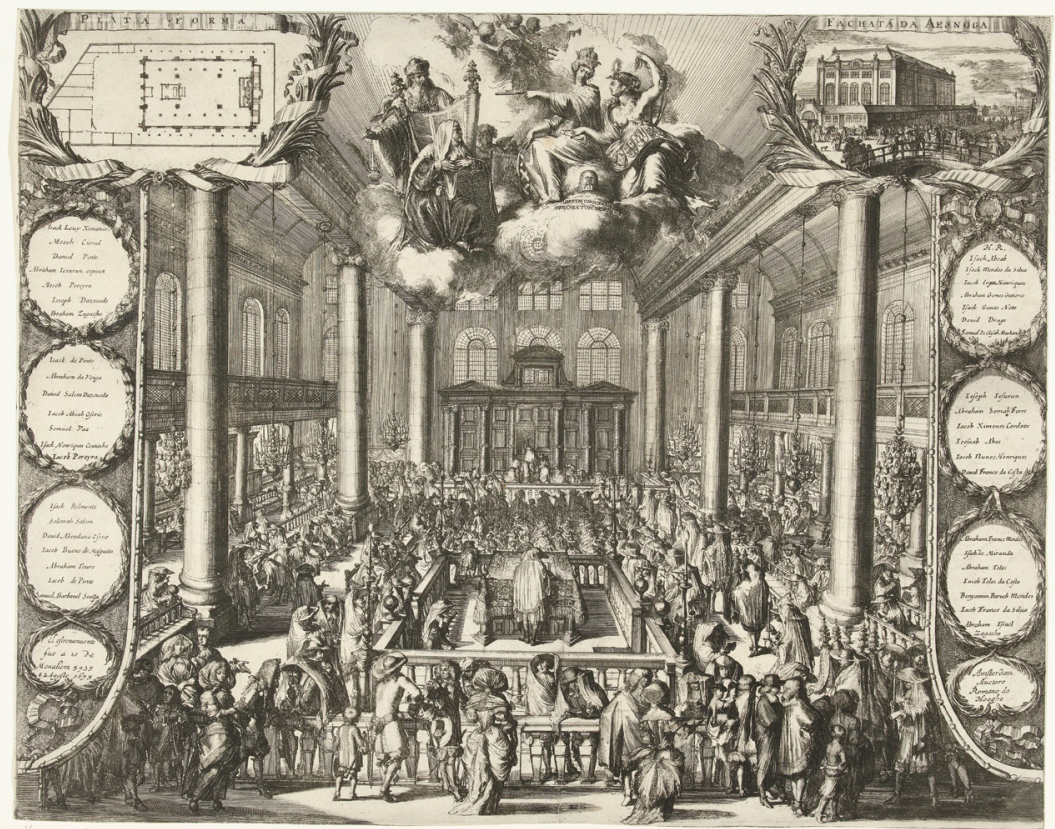

Illustration 5 Romeyn de Hooghe, Interior of the Portuguese synagogue in Amsterdam during the dedication ceremony, 1675 (source: Rijksmuseum, RP-P-OB-67.743A).

ilar to those used in Reformed Churches. We find similar symmetry, arched windows located directly in the brick wall, pilasters being transformed into buttresses as, for instance, in Jacob van Campen's renowned Nieuwe Kerk in Haarlem (1645-1649). In an early plan for the synagogue, Bouwman proposed the same type of buttresses and Doric entablature, including triglyphs, as in Van Campen's church. The surrounding low building structures towards the street and the lack of a bell tower entablature provide the synagogue with a more civilian expression than a typical Dutch church.

The design of the women's galleries in the Esnoga is different from the Houtgracht building discussed above. No longer is there a trellis standing from floor to ceiling, as we can see from Emanuel de Witte's Interieur van de Portugese synagoge te Amsterdam. In the Esnoga, mehitzah is achieved through the distance that exists between the women's balconies and the main floor, which allows for the lattice divider to stop at half of body height. This design allows for a much cleaner style for the space, which is still visually protected from sight-lines from the main floor of the synagogue, but which allows someone who stands on the gallery to see the main floor without the obstruction of a screen. 


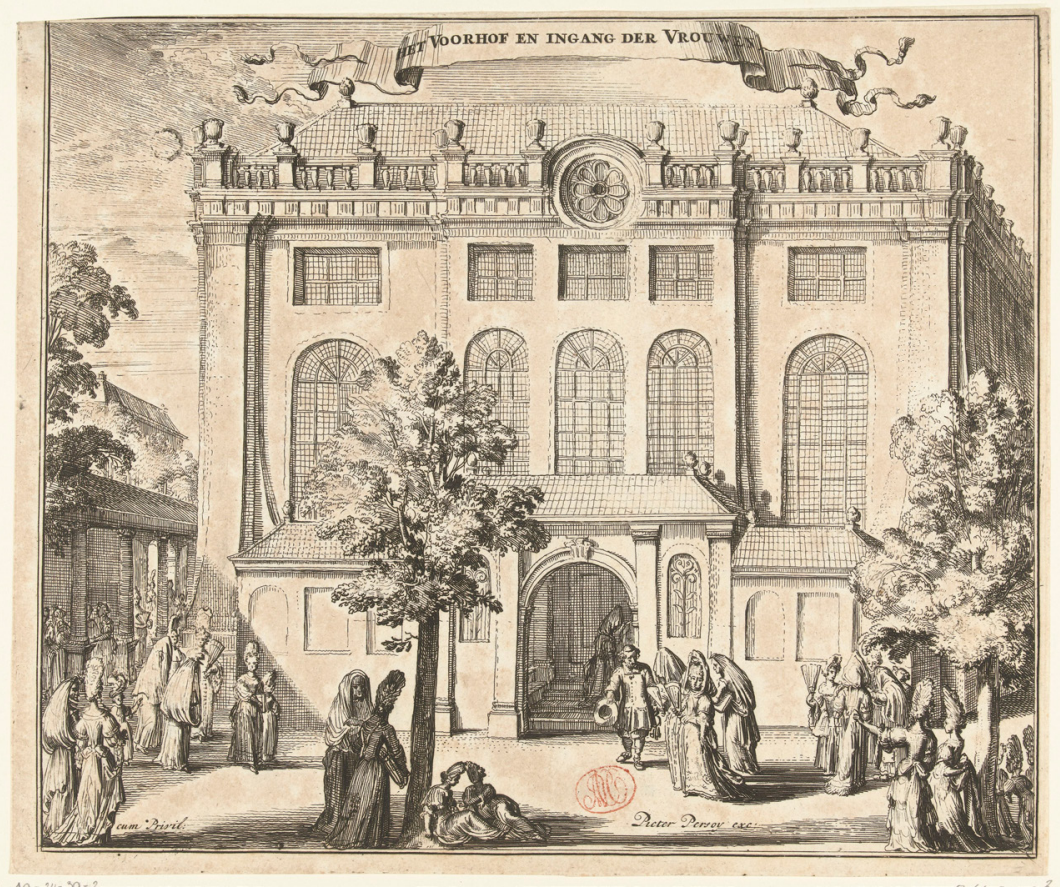

Illustration 6 Romeyn de Hooghe, The courtyard and the women's entrance of the Portuguese synagogue in Amsterdam, c 1695 (source: Rijksmuseum, RP-P-AO-24-30-2).

The women's entrance to the Esnoga is also grander, with an arched door decorated with floral details, as depicted in Romeyn de Hooghe's engraving De Voorhof En de Vrouweningang van de Portugese Synagoge Te Amsterdam.$^{46}$ The interior of the Esnoga is spacious. Ionic columns, again like in Van Campen's Nieuwe Kerk, support an entablature dividing the ceiling and the space into three parts, arched windows cover the walls on all sides, and elegant chandeliers provide candlelight.

As we can see in the discussion above, architectural features of the concealed and visible places of worship used by the Portuguese Nation in seventeenth-century Amsterdam showed traces of the gendered traditional division of religious spaces. The tradition of mehitzah, as well as the differentiation of religious roles according to gender, had a strong influence in the history of the Jewish community, from their flight from persecution in the Iberian Peninsula until their establishment in Amsterdam and beyond.

46 Romeyn de Hooghe, De voorhof en de vrouweningang van de Portugese synagoge te Amsterdam, c 1695, engraving, h $238 \mathrm{~mm} \times$ w 284 mm, Rijksmuseum, http://hdl.handle.net/10934/RMooo1. COLLECT.125115. 
Before the community left the Iberian context, the domestic space was the only space available for their religious observance. Even then, since privacy could not always be guaranteed because of the Inquisition's power of surveillance, secrecy was necessary for survival. In Amsterdam, the community could once again organize dedicated spaces for their religious observance. Here, the tradition of mehitzah shaped the way community members of different genders regulated access between one another. In the first synagogue discussed, women were placed in a hanging room of relatively small proportions, located above the main synagogue floor, where the men were located. Women could see the main floor from window-like apertures, whereas men would scarcely notice women's presence inside the enclosed hanging room. No decoration is mentioned in the plans. In the second synagogue, architectural style is a much more important concern, and women's galleries receive the same attention in terms of space and decoration as the rest of the building. Finally, in the sumptuous Esnoga, the only extant building of all three, the ample space allowed the women's gallery to be in the form of a balcony, where the division between men's and women's space was achieved with only a half-body lattice that did not block sight.

In traditional Sephardic Judaism, religious obligations for men took place mainly in synagogues and yeshivas, which they were unable to access during times of persecution. Women's religious obligations were circumscribed to the home, where they were expected to take care of a range of activities including tending to food, preparing the space, and teaching Jewish customs to the young. Since the domestic space was to a certain extent concealed from hostile authorities - at least in comparison to the synagogue - it was also the only place where some Jewish traditions could be preserved. Thus, women took the role of main purveyors of the Jewish traditions they could manage to maintain and enabled the Sephardic community to survive until they could escape.

Once in Amsterdam, the community had more freedom to exercise their religion and no longer had to remain in secret, despite the fact that they had to practice their religion in private. They remained inconspicuous in order not to disturb the privileged position of the Reformed Church, but they were no longer in danger of forced conversion or persecution just for existing as an acknowledged Jewish community. For women, religious obligations at home remained the norm, but the public space of the synagogue also welcomed them, which we can observe 
in the designed dedicated spaces in each of the buildings analyzed. Finishing elements placed the synagogues within the Dutch baroque aesthetic and provided the whole community with a sense of belonging in this new environment, as well as with the respectability of an affluent community that had access to beautiful, well-planned places of worship.

\section{From public presence to concealment: Amsterdam beguines}

Beguines were Roman Catholic lay religious women who (most commonly) lived in gender-segregated communities. They took simple vows of celibacy and obedience and, in contrast to nuns, were not bound to the community for life. Their vows did not include religious poverty, which meant that they could accumulate wealth, for example, through labour or inheritance. ${ }^{47}$ As mulieres religiosae ${ }^{48}$ beguines had had ecclesiastical approval granted by Pope Innocent III since c. 1200 , a status that afforded them legal standing. This kind of lay religious community flourished in the Low Countries from the thirteenth to the sixteenth century, in a few occasions housing more than 1,00o inhabitants. ${ }^{49}$

The Amsterdam beguines had lived together as a community of women since at least the early fourteenth century..$^{\circ}$ In 1393 , they obtained official status with a privilege signed by the count of Holland, Albrecht of Bavaria. ${ }^{51}$ Having a documented right to enjoy this exclusive space for themselves meant that the Amsterdam beguines had the ability to regulate access to their community. Among the women and their religious leaders, orderly life seems to have been held in high esteem and was systematically supported by internal written documentation. We can glean this from the extensive collection of extant documents from the Beguinage now housed at the Amsterdam City Archives, as well as from the text of individual documents. For example, a privilege

47 Moran, Unconventual women, 3.

48 Walter Simons, Cities of ladies. Beguine communities in the medieval Low Countries, $1200-1565$ (Philadelphia 2010) xi.

49 Ibid., 27.

50 'Overzicht', Archief van het Begijnhof, Gemeente Amsterdam Stadsarchief Archief, accessed August 5, 2019, https://archief.amsterdam/inventarissen/overzicht/740.nl.html.

$5^{1}$ 'Hofbrief of ordinantie van graaf Aelbrecht van Beijeren', 1393, 740: Archief van het Begijnhof, 1.1.1: Notulen, 2, digitized folios A22281000001 to A22281000011, Gemeente Amsterdam Stadsarchief, https://archief.amsterdam/inventarissen/inventaris/740.nl.html\#A22281000oo1. 
from 1389 established property rules in the Begijnhof. The document said that a beguine who bought or built a house in the Court Beguinage was allowed to alienate it only with the consent of the other beguines. ${ }^{5^{2}}$ This document suggests a tendency towards cooperation among the community members, with these written rules serving to protect the women as a group, in addition to the individual, who had her rights over her property clearly delineated. In other words, the documented right to property allowed each beguine to regulate access to her property from other community members but, at the same time, imposed rules for how she could do it, which in turn allowed the community as a whole to regulate access to the space from outsiders.

A later piece of evidence also supports the idea that the community used written documentation to manage communal living, stipulating rights and obligations of one member towards another. A copy from a 1697 document shows a joint declaration made by ten beguines stating that they would clean and tend to the church according to a common agreement, or else they would be liable to pay fines as stipulated in the document. The opening and closing of the document show the communal voice of the members in the use of the first-person plural:

Orders aengaande het veegen in de Kerk, goed gevonden by ons thien Maagden in een maand veegende, om het werk met lubden, vreeden, vreugd en stigting onder ons te doen, tot Glorie en Eere Godts [...] Dit wenschen wy altesamen, dat met liefde en yver agtervolgt mag worden, dewyl wy het selve goed gekeurt hebben, en die dat niet en doet maken wy liever uyt onse vergaderingk quyt. (italics added) $)^{53}$

The tradition of documenting community life in the Beguinage served as protection for the community when religious unrest hit Amsterdam. The documented property of the beguines was honoured by city authorities once the Alteratie came in 1578 , and only the Beguinage chapel was confiscated, which allowed the courtyard and its houses to survive as the living place for the women's community. Today, the still extant Beguinage consists of an enclosed semi-private courtyard surrounded by townhouses. A wooden house dating back to the 1520 still

53 'Verklaring van 10 begijnen, dat zij het kerkegebouw zollen schoonheuden [Declaration of 10 beguines that they will keep the church building clean]'. 
exists, as do two chapels. One of them is the former Beguinage Chapel, which was repurposed as the home of the English Reformed Church in 1607. The second is a concealed chapel, the Church of Saint John and Saint Ursula, which became the Beguines main place of worship as of the 1670 .

Situated in the middle of the courtyard, the former Beguinage chapel was built in the Gothic style sometime during the fifteenth century to replace a chapel that was destroyed by the Great Amsterdam Fire of $1421 .{ }^{54}$ One of Amsterdam's oldest buildings, this church is an example of a late medieval construction with a central nave covered by a barrel vault in wood, and visible wooden posts and ties. Despite having been stripped of Catholic religious adornments when it changed hands at the beginning of the seventeenth century, the chapel still shows architectural features from the Gothic style of the late medieval period. With its central location in the courtyard, this building is representative of a long Roman Catholic architectural tradition with churches that can be described, echoing the words of Willem Frijhoff, as 'proud and eye-catching features in the urban landscape. ${ }^{55}$

When this chapel was confiscated, for a period the Beguinage community could still gather for worship in its sacristy. ${ }^{56}$ Then in 1607 , when the building passed to the control of the English Reformed Church, the beguines lost that space and started congregating in one or more private houses within the Beguinage, though we do not know exactly where. ${ }^{57}$ The Beguinage priest of that period, Leonardus Marius (1588-1652), played an important role in one of these private places of worship at the Beguinage. According to Schillemans, Marius was involved in the interior design of the house church used as of the beginning of the seventeenth century, and he also donated paintings that served as altarpieces there.

54 'Overzicht'.

55 Willem Frijhoff, 'Religious life', in: Idem: Embodied belief. Ten essays on religious culture in Dutch history (Hilversum 2002) 20.

56 Charles Caspers and Peter Jan Margry, 'The miracle on the margins', in: Idem, The miracle of Amsterdam, 77 .

57 Robert Schillemans gives the following overview: 'Hieruit blijkt dat er al in 1605 bij een huis vermeld staat: "noordwaarts de kerk". De plaats van dit huis, en daarmee van de kerk, kon niet worden achterhaald... J. Wagenaar schrijft ... "Doch omtrent den jaare 1620, begon men wederom dienst te doen op ,t Begynhof, in eene byzondere wooning aldaar”. B.Voets vermeldt dat er al voor 1631 een huiskerk was bij Willemtgen Hendriks, tegenover de Engelse kerk. ... In 1636 is er aan het "kercks gebouw" gewerkt (bij Marretge Willems). Er wordt f 1117,- betaald voor onder andere een orgel, een klein altaar en een tabernakel (nr 124 en 134)', Robert Schillemans, 'Zeventiende- en vroegachttiende-eeuwse wisselaltaarstukken in de Amsterdamse Begijnhofkerk', De zeventiende eeuw 15:3 (1999): 'Overzicht'. 


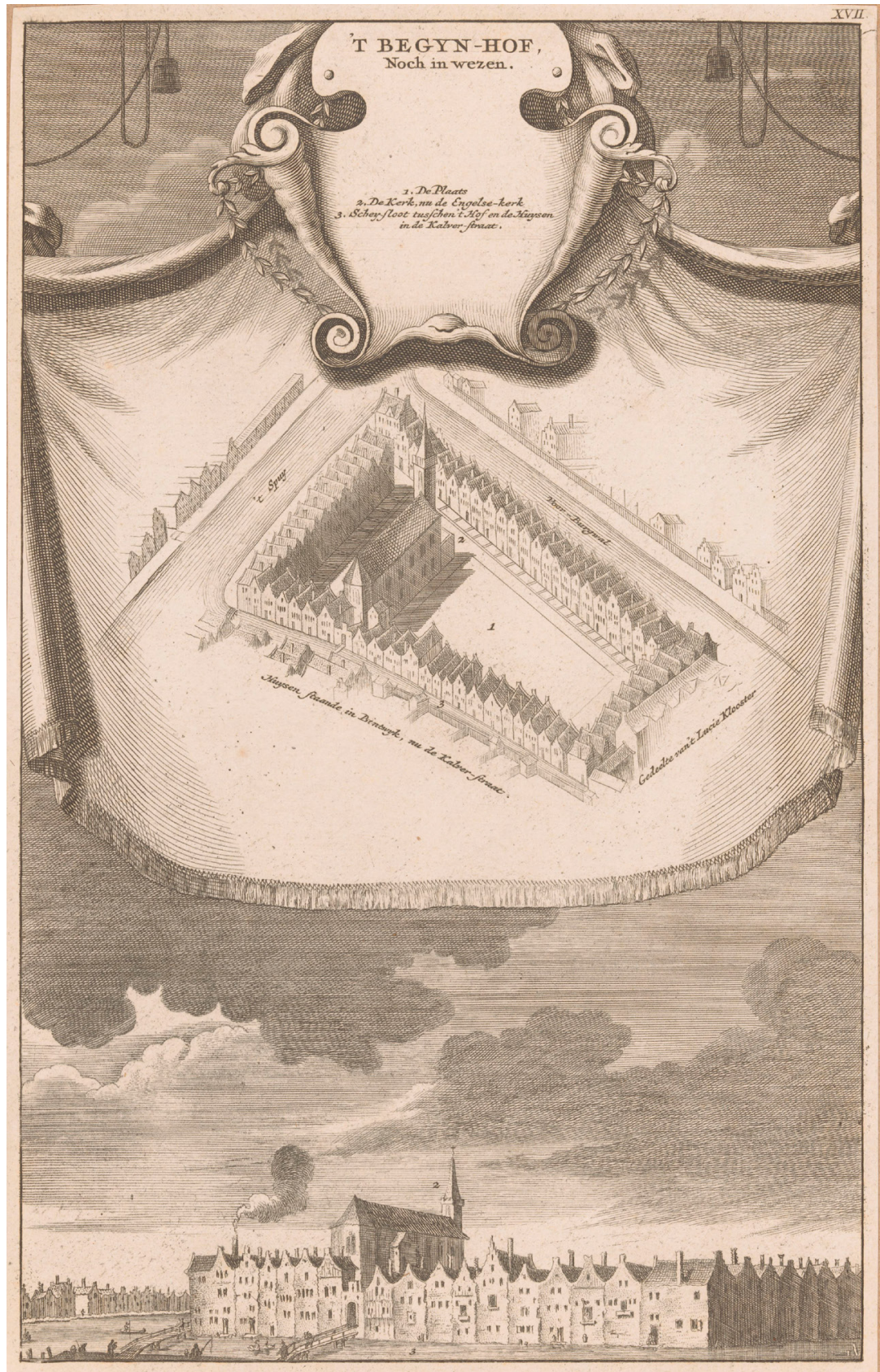

Illustration 7 The Beguinage in Amsterdam, ca. 1544, anonymous, 1760 (source: Rijksmuseum, $R P-P-A O-24 X-34)$. 
After the Alteratie, thanks to the privileges held by the community of women and later to the leadership of Leonardus Marius, the Begijnhof came to have a special significance among Roman Catholics in the city landscape. It came to be a place of worship for followers of the cult of the Sacrament of the Miracle of Amsterdam, since the Holy Stead had been lost at the Alteratie. According to Caspers and Margry,

as the only Catholic institution in the city, [the Beguinage] retained the right to co-opt new residents, as well as close its doors to the outside world at night. This enclosure made it possible for the beguines to hold prayer services each night, making their beguinage a favorite station for priests. ${ }^{8}$

The ability to close its gates to the outside world at night was an important instrument of communal privacy, since the members of the Beguinage could regulate access to their space by controlling when the physical barrier of the gate would be open or closed, in addition to who could come through.

By the 167 os, several Catholic concealed churches had appeared in Amsterdam, which made it possible to envisage plans for a bigger concealed chapel in the Beguinage. ${ }^{59}$ The Beguinage parish priest at this point was David van der Mije (1633-1700), who commissioned the Catholic architect Philips Vingboons (1607-1678) to design the Church of Saint John and Saint Ursula. Philips Vingboons came from a family of painters, architects, engravers, and map-makers. He received training as a painter from his father David Vinckboons (1576-1632), ${ }^{60}$ and in the 1630 s he likely trained as a draftsman under the Dutch architect and painter Jacob van Campen (1596-1657), ${ }^{61}$ one of the first representatives of Dutch baroque classicism. Following this aesthetic line, Philips Vingboons's contributions in architecture are characterized by symmetrical façades, regular building dimensions, and subdued mannerism. ${ }^{62}$

The project for this new chapel required an architectural compromise. On the one hand, the project needed to honour the Roman

58 Caspers and Margry, 'The miracle on the margins', 76-77.

59 Koen Ottenheym, 'Sint Johannes en Ursula aan het Begijnhof', in: Idem, Philips Vingboons ( $1607^{-}$ 1697): Architect (Zutphen 1989) 148.

6o Jacobine E. Huisken \& Friso Lammertse (eds.), Het kunstbedrijf van de familie Vingboons. Schilders, architecten en kaartmakers in de Gouden Eeuw exhibition cataloque (Amsterdam 1989)

61 Ottenheym, Philips Vingboons, 23.

62 Ibid., 163 . 
Catholic tradition of churches with a strong public presence, since some level of aesthetic continuity with the former tradition would be emotionally important for the beguines and other Catholic believers, rendering the new chapel recognizable as a worthy place of worship for the members of the congregation. On the other hand, the new church building should remain inconspicuous from the outside. This arrangement posed many challenges within the architectural parameters in vogue in Amsterdam at the time.

Influenced by the architecture of the Italian Renaissance, the design of early modern Dutch churches tended to follow principles from temples and basilicas of Greek and Roman antiquity. According to Vitruvius's celebrated treatise De architectura, the position of temples in the townscape was important: 'Having laid out the alleys and determined the streets,' Vitruvius says, 'we have next to treat of the choice of building sites for temples, the forum, and all other public places, with a view to general convenience and utility. ${ }^{\prime 3}$ In contrast, according to Vitruvius, the symmetry of a private house could be modified to fit the site available. $^{64}$

For an architect tasked to conceal a church within the size of a private house, it was hard to live up to the ideals of baroque classicism. A typical Dutch grachtenpand (canal house), did not stand out from other houses in the street, as Vitruvius recommended temples should. A canal house's main entrance was usually placed to one side, disrupting symmetry. To follow classical principles, then, an architect had to focus on the interior design of a concealed church, but even here there were challenges. The deep and narrow land plots of the typical canal house, and its many stories, could not easily accommodate a large congregation. Attic churches, which could extend over several floors in the upper part of a canal house and included galleries around the main space, were attempts to deal with the challenges of restricted space. The aforementioned Our Lord in the Attic, from the 166os, exemplifies this design. From about 1670 , the ground floor also started to be used, providing better access and enabling the interior space to become even higher. ${ }^{6}$ The Church of Saint John and Saint Ursula is a surviving example of this development.

65 W. Kuyper, Dutch classicist architecture. A survey of Dutch architecture, gardens and Anglo-Dutch architectural relations from 1625 to 1700 (Delft 1980) 41. 
For the purposes of the building project, a land plot formerly occupied by two houses was cleared next to the tower and entrance of the former chapel, and on 4 June 1671 building started ${ }^{66}$ The Church of Saint John and Saint Ursula shows Vingboons's use of regularity, coherent geometry, and attention to the classical orders. Despite a narrow and irregular site, crammed between existing houses, the interior plan of the chapel is structured after an underlying symmetrical geometry consisting of nine squares ${ }^{67}$ At the same time, the outside brick façade facing the courtyard was ordered in a simple way, with three rows of windows of the same width and a horizontal cornice which made the house, despite its domestic scale, stand out in relation to the surrounding houses with their Dutch gables facing the yard.

Seen from the outside, the chapel was modest and almost unidentifiable as a church building, designed, as it was, with a focus on classicist regularity. A drawing from 1793, which shows the original façade towards the courtyard, ${ }^{68}$ shows arched windows (that could be covered by shutters) whose dimensions were slightly bigger than the windows in the neighbouring houses. The windows on the ground floor have a proportion of two squares and the windows on the second floor have the proportion of one square. ${ }^{69}$ Judging by the current state of the building (whose façade was extended in 1880), on the back of the chapel facing the Nieuwezijds Voorburgwal, there were no windows at ground floor level.

The interior of the church could more easily accommodate its religious aesthetic program. Here the challenges were different, namely, an irregular and narrow site and dimensions combining limited space on the ground floor with great height. In the interior of the chapel, galleries on the first floor surround a central space on three sides. On the fourth side, opposite the entrance, we find the altar, which spans almost the entire height of the central space. This central space continues on the second floor where the galleries on the two long sides were replaced by three arched windows in the middle of the chapel, throwing daylight onto the high altar. Finally, the central space is covered with a vaulted ceiling emphasizing the longitudinal direction of the space. This kind of ceiling was not uncommon in Dutch seventeenth-century church ar-

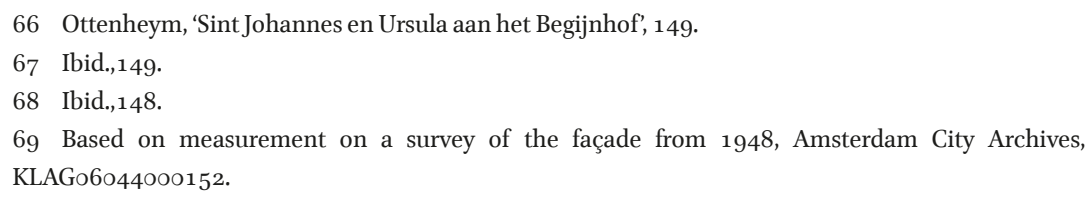


chitecture, while also referring to the barrel-vaulted wooden ceiling in the former chapel of the Beguinage.

On the one hand, this spatial design is reminiscent of a medieval basilica structure, where a high central nave defines the middle of the church and its longitudinal direction, while low lateral aisles on sides give space for upper Triforium galleries and, above these, big clerestory windows. On the other hand, the central space is not wider than the aisles and not long enough for a nave in a basilica. Using an underlying nine square geometry to organize the plan, Vingboons combines the typology of the basilica with a typology of central churches. The high clerestory windows emphasize the centre of the chapel and evoke an almost cathedral-like character in the otherwise cramped space.

Despite its limited size, the chapel has spatial complexity with competing centres and directions sometimes found in baroque churches with juxtaposed decorative systems and ambiguous spatial qualities. Vingboons makes the limited space grander through the introduction of a central space with high windows for letting in daylight which supplement the other windows in the façades. These windows turn to the gallery spaces, or aisles, in the interior of the chapel. The two arched windows on the ground floor (removed in the renovation of 1880), together with the clerestory windows at the top, served to emphasize the altar as the most sacred part of the space.

Vingboons may have thought the Tuscan order was appropriate for the galleries of a private chapel. At the same time, using it for the galleries helped to highlight the importance of the altar along with the side altars, which were all framed by the more prominent Corinthian order. The current main altar is from the late nineteenth century, but the original Corinthian order was maintained. ${ }^{70}$ This order was also used - in a simplified version - in the smaller pilasters that flank the clerestory windows. Thus, the upper space becomes more important, and Vingboons follows classicist rules by putting the lighter Corinthian order also on top of the galleries. In this way, he establishes a hierarchy in his decorative apparatus, and the individual parts become interrelated.

The next level of decoration consisted of secondary spatial elements such as balusters, sculptures, reliefs, consoles, and the pediment above the altar. In the side altars, the entablature was just transformed into a pediment. The balusters on the galleries were shaped in a relatively conventional way with only one swollen section, or belly, which suits 


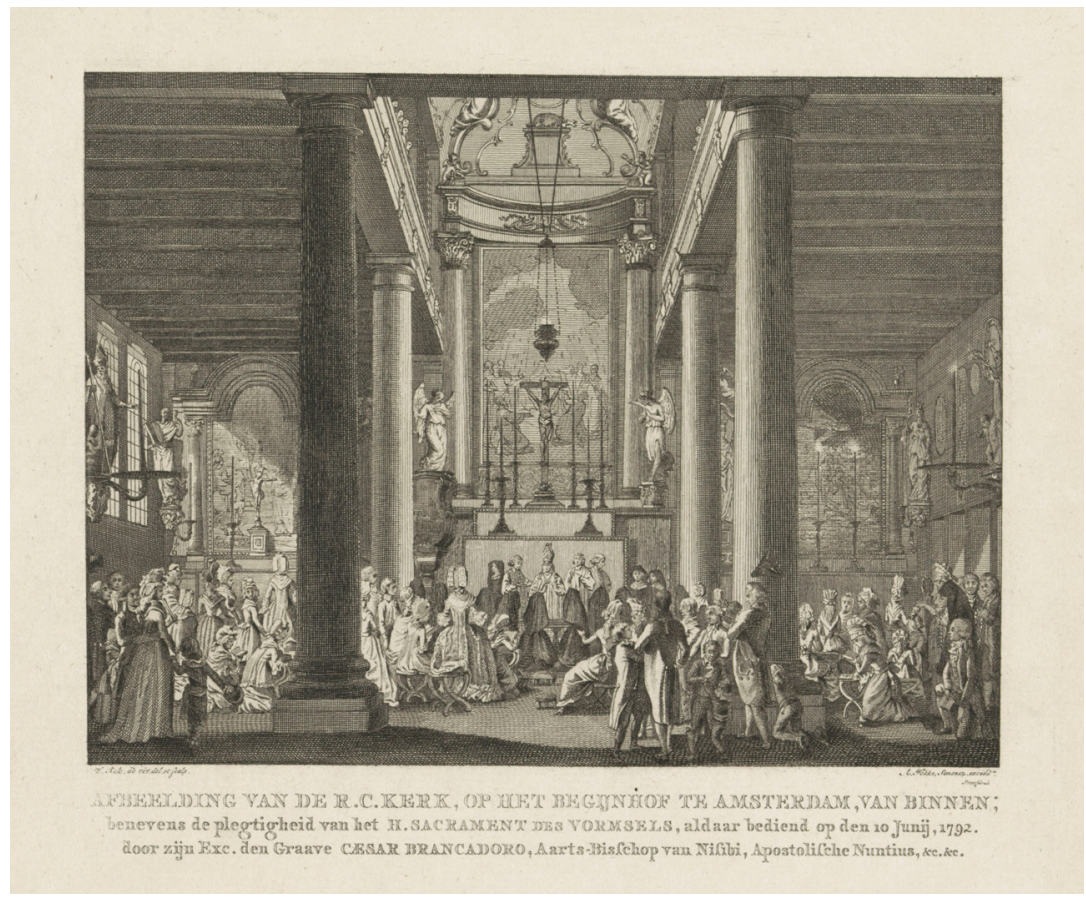

Illustration 8 Willem Kok, Confirmation ceremony at the Beguinage church in Amsterdam, 1792 (source: Rijksmuseum, RP-P-OB-86.210).

the Tuscan columns well. The sculptures of saints are located above head height on consoles, flanking the side altars and the main altar. On an etching titled Toediening van het vormsel in de kerk op het Begijnhof te Amsterdam by Willem Kok, showing the interior of the chapel during a service in 1792, these sculptures have the same size and presence in the space as the audience. ${ }^{71}$ They appear almost like human bodies attending the sacrament together with the congregation. Daylight from the windows above the galleries in the nave is directed towards the altar, enhancing its height in the otherwise narrow space and, in so doing its spiritual dimension. The side altar to the right was also bathed in light. The architectural details referred to a coherent classical system where everything reflected cosmic harmonies, from the attention to proportions to the hierarchy of orders in the eyes of the believer. The statues of saints helped to mediate a relationship between the divine realm 
and the church attendee's own mortal body. ${ }^{72}$ Outside of the chapel, it was not feasible to build an impressive façade by turning the decorative apparatus of the interior outwards, as it would normally be done in a baroque church. The outside had to remain discreet as a way to regulate the visibility of the Catholic chapel and preserve the privileged status of the Reformed Church.

In the case of the Beguinage chapel, we can see that, in contrast with the synagogues discussed above, norms of separation between the genders did not play a strong role in the interior design of the church. The gendered norms for the use of space in the case of the Catholic beguines worked on a different level, that is, between the city administration and the community. Gendered norms for the use of space had shaped the lives of this religious women's community since the fourteenth century, but it applied mostly to relations between the community and the wider Amsterdam society.

As religious women, beguines lived in a space apart, and had the right to regulate this space, but the women retained the ability also of remaining active in the societal life. Their orderly communal life was supported by internal documentation, and the community also encouraged internal coherence as well as good relationships with its religious leaders. Once the Alteratie changed the status of Catholics in the city, the Beguinage managed to remain a place for the use of this community of women due to the long and documented tradition that preserved their rights there before city authorities. Within their own space, the community of women enjoyed the use of private house chapels thanks to the mutual collaboration between themselves and their religious leaders. Once the situation became amenable, the Beguinage's private places of worship could be upgraded with the construction of the concealed Church of St. John and St. Ursula, which still stands today.

\section{Conclusion}

Gendered norms for the use of spaces had existed for the two communities here studied well before the seventeenth century. In the case of the Jews, women were responsible for the religious activities in the home, while men exercised their religious learning mainly in yeshivas and synagogues. Among women's religious obligations were activ- 
ities such as observing dietary laws, teaching prayers and rituals to the young, and caring for spaces in the home as well as in the synagogue. Because most of their religious activities took place in the home, where these activities were less conspicuous, women became the main purveyors of Jewish customs among those who wished to continue in the Jewish tradition in the hostile environment of the Iberian Peninsula. They all had to practice their religion not only in privacy but in strict secrecy as well. Once in Amsterdam, this habit of private religious practice helped the community of the Portuguese Nation to remain religiously inconspicuous.

In the case of the beguines, the fact that they were laywomen who eschewed marriage, dedicated themselves to religious activities, and preferred to live in the company of other women was important for how the physical space of the Begijnhof came to exist, grow, and be preserved in the city of Amsterdam. Beguines did not make vows of poverty and could have property, and since they had official recognition from the church and secular authorities, they also enjoyed legal standing. In the sixteenth century, the fact that beguines had this long history of protected privileges to private property made a difference. Despite the confiscations of Catholic buildings that ensued from the Alteratie, the beguines' houses were documented as their property, and so they managed to keep their houses for their own use. Their courtyard church, however, was not protected - it belonged to the institution of the Roman Catholic Church - and was repurposed for the use of the Reformed Church.

As we saw, each religious community had its own traditions and rules of spatial separation of men and women, both sharing a tendency to protect the domestic realm as women's privileged space. Once the socio-political status of each religion changed, such traditions acquired wider, perhaps unforeseen, repercussions for each community. For the Jews of the Portuguese Nation, it had been thanks to the resistance of women, who acted as keepers of Jewish customs at home in the Iberian Peninsula, that they managed to relocate to a place like Amsterdam. Once there, they acquired a heightened level of religious freedom. In Amsterdam, the Sephardim could exercise greater participation in public life as a cohesive - Jewish - community. Though their religious practice had to remain private, they were allowed to exist and be present in the city as Jewish without the threat of forced conversion. The women of the Portuguese Nation were part and parcel of the community's visible existence, enjoying both their traditionally established domestic 
role in religious life, as well as dedicated spaces in the synagogues built according to architectural practices current in Amsterdam.

For Catholics, the now undermined position of their religion in Amsterdam imposed the need to make compromises on how they participated in public life. In the specific case of the Amsterdam beguines, they had to navigate as women the highs and lows of political and religious change in the city. Their official status before the Catholic Church empowered them with legal standing and the protections that the law afforded. Because they had documents granting them control of their land and houses, the community could stay put in their Begijnhof, their space eventually serving as a bastion of the Catholic faith also for the wider community. The beguines did lose their courtyard church, but later in the seventeenth century, those same documented property rights enabled the institutionalized female community, through its male religious leaders, to advocate for the construction of a concealed church as a replacement, on a piece of land within the Beguinage. This concealed church was constructed according to the principles of Dutch baroque architecture and shared aesthetic elements with other buildings of the era. The aesthetics choices made in the construction of the concealed church demonstrate the compromise on religious privacy, where interior decorative elements could be visible and exterior decoration had to remain discreet.

Studying the places of worship used by the Roman Catholic Beguines and the Sephardic Jews of the Portuguese Nation in seventeenth-century Amsterdam provides us with interesting clues about the gendered dimensions of early modern privacy for religious purposes. For both of these communities, spaces for religious practice had been traditionally organized according to a concern for gendered separation. Yet each religion had their own ways and their own reasons for separating the genders. In the situation of political change discussed above, the practice of gender separation acquired added significance. Our analysis of aesthetic, social, religious, and legal historical traces highlight how these multiple dimensions intersected with the gendered traditions of each community to shape their experience of religious privacy in seventeenth-century Amsterdam.

\section{About the authors}

Natália da Silva Perez (1982) is a postdoctoral researcher at the Centre for Privacy Studies at the University of Copenhagen. She holds a joint PhD from the University of Kent and the Freie Universität Berlin. From a trans- 
national and comparative perspective, her current research focuses on privacy as experienced by early modern women of high and low social status, including how women's access to it was influenced by their families, communities, and authorities. Her most recent publication is the chapter "Sexual Surveillance in Paris and Versailles under Louis XIV" in Histories of Surveillance from Antiquity to the Digital Era: The Eyes and Ears of Power, edited by Andreas Marklund and Laura Skouvig (Routledge, 2021). E-mail:nsp@teol.ku.dk

Peter Thule Kristensen (1966) is a professor in history of architecture and interior at The Royal Danish Academy, where he also is head of the master program Spatial Design and core scholar at the Centre for Privacy Studies. Selected monographs: Gottlieb Bindesbøll - Denmark's first Modern Architect, 2013, Svenn Eske Kristensen - Velfcerdsarkitekten, 2017 and Klein: Arkitekten Vilhelm Kleins skrifter og historicismen i Danmark, 2019. E-mail:pthul@kglakademi.dk 